\title{
Clinical characteristics and corticosteroid treatment of acute eosinophilic pneumonia
}

\author{
Chin Kook Rhee*,f, Kyung Hoon Min ${ }^{\#, f}$, Nam Yeol Yim ${ }^{\star}$, Ji Eun Lee ${ }^{+}$, Na Rae Lee ${ }^{+}$, \\ Man Pyo Chung ${ }^{\S}$ and Kyeongman Jeon ${ }^{\S}$
}

\begin{abstract}
The clinical characteristics and optimal duration of corticosteroid treatment for acute eosinophilic pneumonia (AEP) have not been fully evaluated. This was a retrospective study of prospectively collected data from 137 patients with AEP, treated with standardised protocol, to clarify the clinical characteristics and compare the efficacies of 2 weeks versus 4 weeks of corticosteroid treatment for AEP.
\end{abstract}

The majority of the patients altered their smoking habits within a median (interquartile range) of 17 (13-26) days prior to development of AEP. $80(58 \%)$ patients presented with acute respiratory failure. A total of 127 (92\%) patients were treated with corticosteroids: 4 weeks, $n=42$; 2 weeks, $\mathbf{n}=85$. Major symptoms were resolved in 3 days and the severity of respiratory failure was inversely correlated with clinical outcomes. After adjusting for differences in baseline characteristics between the groups, the differences in adjusted mean (95\% confidence interval) for resolution of dyspnoea and disappearance of all symptoms were $0.57(-0.71-1.86)$ and -0.04 $(-1.91-1.83)$ days, respectively. The difference in adjusted proportion of resolution of radiological abnormalities was $6.92 \%(-8.19-22.02)$.

In conclusion, the duration of corticosteroid treatment could be shortened to 2 weeks, even in patients with respiratory failure.

KEYWORDS: Acute disease, pulmonary eosinophilia, respiratory insufficiency, smoking, treatment outcome

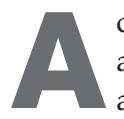
cute eosinophilic pneumonia (AEP) is an acute febrile illness with severe hypoxaemia, diffuse pulmonary infiltrates, an increase in bronchoalveolar lavage (BAL) eosinophils and no evidence of infection or previous atopic illness [1]. Less than 100 cases of AEP have been reported to date [2], with the largest series including only 33 patients [3]. Therefore, clinical characteristics, especially the course of resolution of symptoms and resolution of radiographic abnormalities, have not yet been fully evaluated.

AEP is also characterised by rapid response to corticosteroids with few relapses and improvement of radiographic abnormalities without fibrosis [1, 4]. However, the proposed corticosteroid regimen varies greatly with a wide range of recommended dosages. The optimal duration of corticosteroid treatment is also uncertain, and there have been no controlled trials to guide clinicians in their use of corticosteroids. In addition, there are several reports of patients improving spontaneously without corticosteroid treatment $[3,5,6]$.

A retrospective analysis of clinical data from 137 cases of AEP was performed to clarify clinical characteristics, including resolution of associated symptoms and resolution of radiological abnormalities, after corticosteroid treatment. In addition, the efficacy and safety of a short course (2 weeks) of corticosteroid treatment was compared to a long course ( 4 weeks) of treatment.

\section{MATERIALS AND METHODS}

The medical records of all consecutive patients who were diagnosed with AEP at the Armed Forces Capital Hospital, an 874-bed referral military hospital in Gyeonggi province, South Korea, between May 2007 and October 2010 were retrospectively reviewed. The study was approved by the institutional review board of the Armed Forces Capital Hospital to review and publish information from the patients' records. The requirement for informed consent was waived because of the retrospective nature of the study.

All consecutive patients who were suspected to have AEP with a febrile illness with respiratory symptoms and diffuse pulmonary infiltrates were prospectively registered for the study period. Definite diagnosis of AEP was based on a

\section{Study subjects}

AFFILIATIONS

*Division of Pulmonary and Critical Care Medicine, Dept of Internal Medicine, Seoul St. Mary's Hospital, College of Medicine, Catholic University of Korea,

\#Division of Respiratory Medicine, Dept of Internal Medicine, Korea University Guro Hospital, Korea University Medical School,

${ }^{\S}$ Division of Pulmonary and Critical Care Medicine, Dept of Medicine, Samsung Medical Center,

Sungkyunkwan University School of Medicine, Seoul,

"Dept of Diagnostic Radiology,

Chonnam National University Hospital, Chonnam National University Medical School, Gwangju, and

+Division of Pulmonary and Critical Care Medicine, Dept of Internal Medicine, The Armed Forces Capital Hospital, Seongnam, Republic of Korea

${ }^{f}$ Both authors contributed equally.

\section{CORRESPONDENCE}

K. Jeon

Division of Pulmonary and Critical

Care Medicine

Dept of Medicine

Samsung Medical Center

Sungkyunkwan University School of Medicine

81 Irwon-ro

Gangnam-gu Seoul

135-710

Republic of Korea

E-mail: kjeon@skku.edu

Received:

Dec 172011

Accepted after revision:

May 072012

First published online:

May 172012

European Respiratory Journal

Print ISSN 0903-1936

Online ISSN 1399-3003 
modification of criteria proposed by PHILIT et al. [5] as followed: 1 ) acute onset of febrile respiratory manifestations $<1$ month in duration; 2) bilateral diffuse infiltrates on chest radiograph; 3) $>25 \%$ eosinophils on BAL or eosinophilic pneumonia on lung biopsy; and 4) absence of known causes of pulmonary eosinophilia including drugs, toxins and infections. Unlike PHILIT et al. [5], patients with or without hypoxaemia were included to identify all possible cases of AEP [7].

\section{Baseline data, treatment protocol and measurements during follow-up}

The following data were recorded at the time of presentation: general characteristics of the patients including demographic data, detailed smoking history including the duration of smoking, symptoms and signs, and laboratory measurements including arterial oxygen tension $\left(\mathrm{Pa}_{\mathrm{a}} \mathrm{O}_{2}\right)$ /inspiratory oxygen fraction $\left(F \mathrm{I}, \mathrm{O}_{2}\right)$ ratio. In all instances, patients were interviewed about exposures that may have resulted in pulmonary eosinophilia and drug histories were reviewed. In addition, patients with a history of eating raw or undercooked freshwater crab or crayfish underwent evaluation for potential parasite infection and serologic tests. Chest radiograph and high-resolution computed tomography (HRCT) of the lungs were performed for all patients. Bronchoscopy with BAL was carried out at the time of presentation based on the constellation of clinical and radiological findings. BAL was performed using the standard techniques as previously described [8]. Once wedged, $30 \mathrm{~mL}$ of normal saline at room temperature was instilled through the bronchoscope and was then retrieved using a negative suction pressure adjusted to avoid visible airway collapse ( $<100 \mathrm{mmHg}$ ). The procedure was then repeated until a total of at least $120 \mathrm{~mL}$ was instilled. The percentages of eosinophils in BAL fluid were determined on cytocentrifuged slides using standard criteria.

After confirmative diagnosis of AEP was made, corticosteroid treatment was initiated according to a standardised protocol. The attending physician chose a regimen based on the presence of respiratory failure defined as a $\mathrm{Pa}_{1} \mathrm{O}_{2} / \mathrm{FI}_{1} \mathrm{O}_{2}$ ratio $\leqslant 300$ and/or tachypnea (respiration rate $>30$ breaths $\cdot \mathrm{min}^{-1}$ ). When the patient had respiratory failure, $60 \mathrm{mg}$ of mehyprednisolone was administered intravenously every $6 \mathrm{~h}$ for 3 days and then changed to $30 \mathrm{mg}$ oral prednisolone twice a day (fig. 1). When the patient had no respiratory failure, $30 \mathrm{mg}$ oral prednisolone was administered twice a day (fig. 1). When the oxygenation was not severe $\left(\mathrm{Pa}_{1} \mathrm{O}_{2} / \mathrm{FI}, \mathrm{O}_{2}\right.$ ratio $\left.>350\right)$ and dyspnoea symptoms were mild, corticosteroids were not administered. From May 2007 to May 2008, 4-week corticosteroid treatment was administered. However, in June 2008, the treatment duration was reduced to 2 weeks because of potential side-effects of longterm corticosteroid use. From June 2008 to March 2009, both 4-week and 2-week treatments of corticosteroids were administered. From April 2009 to October 2010, only 2-week corticosteroid treatments were administered. These regimens of corticosteroid treatment are described in figure 1.

During treatment, clinical symptoms and signs were evaluated daily by an attending physician. Moreover, laboratory tests and chest radiographs were performed weekly. Follow-up HRCT was performed 14 days after the initiation of corticosteroid treatment. The time to resolution of individual vital signs and clinical status abnormalities was defined as the first day that the vital sign or clinical variable was stable [9].

\section{Evaluation of radiological findings}

Chest radiographs were reviewed for the presence of pulmonary infiltrates and pleural fluids. HRCT images were also reviewed for the presence of each of the following signs: ground-glass opacity, air-space consolidation, nodular opacity, interlobular septal thickening, thickening of bronchovascular bundle, and pleural effusion [10]. During follow-up, clearances of pulmonary infiltrates and pleural effusion, defined as the absence of any radiographic sign, were established. Radiological findings were retrospectively analysed by two of the authors (C.K. Rhee N.Y. Yim). Differences in observed findings were resolved by consensus.

\section{Data analysis}

Because the majority of the data did not follow a normal distribution, all results are presented as median (interquartile range (IQR)) or $\mathrm{n}(\%)$. Categorical variables were analysed using Pearson's Chi-squared tests or Fisher's exact tests. Continuous variables were analysed using Mann-Whitney U-tests. Spearman's correlation coefficient, rho $(\rho)$, was used to assess whether there was a relationship between $\mathrm{Pa}, \mathrm{O}_{2} / \mathrm{FI}_{1} \mathrm{O}_{2}$ ratio at the time of presentation and clinical outcomes, including resolution of associated symptoms and signs, and intensive care unit (ICU) stay. In order to compare the efficacies of 2 weeks versus 4 weeks of corticosteroid treatment, differences in baseline characteristics between the two groups were adjusted if the p-value was $<0.2$ [11]. Adjusted mean time to resolution of individual clinical symptoms was calculated using a general linear model. Adjusted proportion of patients with pulmonary infiltration on HRCT at day 14 was calculated by logistic regression analysis. All tests were two-sided, and a p-value $<0.05$ was considered statistically significant.

\section{RESULTS}

During the study period, 160 patients suspected to have AEP were entered into the registry. Out of these patients, $22(14 \%)$ patients were excluded because eosinophils on BAL were $<25 \%$, even though it was also increased (12-25\%). In addition, a patient diagnosed with 2009 influenza A (H1N1)-associated AEP was excluded from the study [12]. Ultimately, 137 patients with a definite diagnosis of AEP were included in this study.

\section{Clinical characteristics}

The clinical characteristics at the time of presentation of 137 patients with AEP are shown in table 1 . All patients were young males with a median (IQR) age of 20 (19-21) yrs. 135 (99\%) patients were current smokers. In the month prior to developing AEP, 71 of these patients had started smoking with no previous history of smoking, 41 had restarted smoking after at least $1 \mathrm{yr}$ of cessation, and 13 had increased the number of cigarettes smoked per day. Of the 125 patients who had recently changed their smoking habits, the time from initiation of smoking or increased number of cigarettes to presentation of symptoms was 17 (13-26) days. 16 (12\%) patients had a pre-existing allergic disease. However, other causes related to pulmonary eosinophilia were not found. Most common symptoms were cough $(95 \%)$, dyspnoea $(92 \%)$ and fever $(88 \%)$. The level of fever was higher in patients with chills $\left(38.2(37.4-39.0)^{\circ} \mathrm{C}\right)$ compared to patients without chills $\left(37.2(37.2-38.2)^{\circ} \mathrm{C} ; \mathrm{p}<0.001\right)$. Inspiratory crackles were present on chest auscultation in $92(67 \%)$ patients. A total of $108(79 \%)$ patients were admitted to the ICU and 29 


\begin{tabular}{|c|c|c|c|c|}
\hline \multirow[t]{2}{*}{ Days } & \multicolumn{2}{|c|}{ 4-week treatment course } & \multicolumn{2}{|c|}{ 2-week treatment course } \\
\hline & Respiratory failure & $\begin{array}{c}\text { No respiratory } \\
\text { failure }\end{array}$ & Respiratory failure & $\begin{array}{c}\text { No respiratory } \\
\text { failure }\end{array}$ \\
\hline D1 & \multirow{3}{*}{$\begin{array}{c}\text { Intravenous } \\
\text { methylprednisolone } \\
60 \mathrm{mg} \text { every } 6 \mathrm{~h}\end{array}$} & \multirow{10}{*}{$\begin{array}{l}\text { Oral prednisolone } \\
30 \mathrm{mg} \text { twice a day }\end{array}$} & \multirow{3}{*}{$\begin{array}{c}\text { Intravenous } \\
\text { methylprednisolone } \\
60 \mathrm{mg} \text { every } 6 \mathrm{~h}\end{array}$} & \multirow{7}{*}{$\begin{array}{l}\text { Oral prednisolone } \\
30 \mathrm{mg} \text { twice a day }\end{array}$} \\
\hline D2 & & & & \\
\hline D3 & & & & \\
\hline D4 & \multirow{7}{*}{$\begin{array}{l}\text { Oral prednisolone } \\
30 \mathrm{mg} \text { twice a day }\end{array}$} & & \multirow{4}{*}{$\begin{array}{l}\text { Oral prednisolone } \\
30 \mathrm{mg} \text { twice a day }\end{array}$} & \\
\hline D5 & & & & \\
\hline D6 & & & & \\
\hline D7 & & & & \\
\hline D8 & & & \multirow{3}{*}{$\begin{array}{l}\text { Oral prednisolone } \\
20 \mathrm{mg} \text { twice a day }\end{array}$} & \multirow{3}{*}{$\begin{array}{l}\text { Oral prednisolone } \\
20 \mathrm{mg} \text { twice a day }\end{array}$} \\
\hline D9 & & & & \\
\hline D10 & & & & \\
\hline D11 & \multirow{3}{*}{$\begin{array}{l}\text { Oral prednisolone } \\
25 \mathrm{mg} \text { twice a day }\end{array}$} & \multirow{3}{*}{$\begin{array}{l}\text { Oral prednisolone } \\
25 \mathrm{mg} \text { twice a day }\end{array}$} & \multirow{2}{*}{$\begin{array}{l}\text { Oral prednisolone } \\
20 \mathrm{mg} \text { once a day }\end{array}$} & \multirow{2}{*}{$\begin{array}{l}\text { Oral prednisolone } \\
20 \mathrm{mg} \text { once a day }\end{array}$} \\
\hline D12 & & & & \\
\hline D13 & & & \multirow{2}{*}{$\begin{array}{l}\text { Oral prednisolone } \\
10 \mathrm{mg} \text { once a day }\end{array}$} & \multirow{2}{*}{$\begin{array}{l}\text { Oral prednisolone } \\
10 \mathrm{mg} \text { once a day }\end{array}$} \\
\hline D14 & \multirow{3}{*}{$\begin{array}{l}\text { Oral prednisolone } \\
20 \mathrm{mg} \text { twice a day }\end{array}$} & \multirow{3}{*}{$\begin{array}{l}\text { Oral prednisolone } \\
20 \mathrm{mg} \text { twice a day }\end{array}$} & & \\
\hline D15 & & & & \\
\hline D16 & & & & \\
\hline D17 & \multirow{3}{*}{$\begin{array}{l}\text { Oral prednisolone } \\
15 \mathrm{mg} \text { twice a day }\end{array}$} & \multirow{3}{*}{$\begin{array}{l}\text { Oral prednisolone } \\
15 \mathrm{mg} \text { twice a day }\end{array}$} & & \\
\hline D18 & & & & \\
\hline D19 & & & & \\
\hline D20 & \multirow{3}{*}{$\begin{array}{l}\text { Oral prednisolone } \\
15 \text { mg once a day }\end{array}$} & \multirow{3}{*}{$\begin{array}{l}\text { Oral prednisolone } \\
15 \mathrm{mg} \text { once a day }\end{array}$} & & \\
\hline D21 & & & & \\
\hline D22 & & & & \\
\hline D23 & \multirow{3}{*}{$\begin{array}{l}\text { Oral prednisolone } \\
10 \mathrm{mg} \text { once a day }\end{array}$} & \multirow{3}{*}{$\begin{array}{l}\text { Oral prednisolone } \\
10 \mathrm{mg} \text { once a day }\end{array}$} & & \\
\hline D24 & & & & \\
\hline D25 & & & & \\
\hline D26 & \multirow{3}{*}{$\begin{array}{l}\text { Oral prednisolone } \\
5 \text { mg once a day }\end{array}$} & \multirow{3}{*}{$\begin{array}{l}\text { Oral prednisolone } \\
5 \text { mg once a day }\end{array}$} & & \\
\hline D27 & & & & \\
\hline D28 & & & & \\
\hline
\end{tabular}

FIGURE 1. Standardised treatment protocol for acute eosinophilic pneumonia at the Armed Forces Capital Hospital, Seongnam, Republic of Korea.

(21\%) patients to a general ward. $80(58 \%)$ patients presented with respiratory failure with decreased oxygenation $\left(\mathrm{Pa}, \mathrm{O}_{2} / \mathrm{FI}_{1} \mathrm{O}_{2}\right.$ ratio $<300)$; however, mechanical ventilation was needed for only three ( $2 \%$ ) patients, two of whom were intubated.

\section{Laboratory findings}

Laboratory findings at the time of presentation are shown in figure 1. Leukocytosis of peripheral blood $\left(>10,000\right.$ cells $\left.\cdot \mu \mathrm{L}^{-1}\right)$ was seen in $97(71 \%)$ patients. Eosinophilia $\left(>500\right.$ cells $\left.\cdot \mu \mathrm{L}^{-1}\right)$ was detected in the peripheral blood of $44(32 \%)$ patients whose median level of eosinophil was 719 (593-997) cells $\mu \mathrm{L}^{-1}$. The median $\mathrm{Pa}_{\mathrm{a}} \mathrm{O}_{2} / \mathrm{FI}, \mathrm{O}_{2}$ ratio at initial presentation was 284.3 (232.7-334.1). Bronchoscopy with BAL was performed in all patients on the day of presentation, and the median percentage of eosinophils on BAL fluid was $40(35-53) \%$. The percentage of lymphocyte fluid was also elevated $19(12-28) \%$. There were no bacterial, fungal or parasitic isolates from BAL fluid.

\section{Radiological findings}

HRCT findings at the time of presentation are shown in table 2. The most common finding was ground-glass opacity in 133 $(97 \%)$ patients, followed by pleural effusion in $121(88 \%)$ patients. Interlobular septal thickening was present in $93(68 \%)$ patients. Centrilobular nodules were present in $71(52 \%)$ patients and all cases had poorly defined centrilobular nodules. In addition, air-space consolidation was found in 51 $(37 \%)$ patients and thickening of bronchovascular bundles was present in $24(18 \%)$ patients. However, air-space consolidation was more frequently observed in patients with respiratory failure compared to patients without respiratory failure $(47 \%$ versus $19 \% ; \mathrm{p}=0.002)$.

\section{Treatment response and follow-up}

A total of 127 (92\%) patients were treated with corticosteroids at the time of AEP diagnosis (table 3). Among them, 90 patients 


\begin{tabular}{|c|c|c|}
\hline TABLE 1 & \multicolumn{2}{|c|}{$\begin{array}{l}\text { Clinical characteristics and laboratory findings at } \\
\text { the time of presentation in } 137 \text { patients with } \\
\text { acute eosinophilic pneumonia (AEP) }\end{array}$} \\
\hline \multicolumn{3}{|c|}{ Characteristics } \\
\hline Age yrs & & $20(19-21)$ \\
\hline Male & & $137(100)$ \\
\hline History of al & rgic disease & $16(12)$ \\
\hline Rhinitis & & 10 \\
\hline Dermatitis & & 3 \\
\hline Bronchial as & Ima & 3 \\
\hline \multicolumn{3}{|c|}{ Smoking history } \\
\hline Current smo & & $135(99)$ \\
\hline Started sm & king within 1 month of developing AEP & 71 \\
\hline $\begin{array}{r}\text { Resumed } s \\
\text { after ces }\end{array}$ & $\begin{array}{l}\text { loking within } 1 \text { month of developing AEP } \\
\text { ation }\end{array}$ & 41 \\
\hline $\begin{array}{l}\text { Increased } r \\
1 \text { month }\end{array}$ & $\begin{array}{l}\text { mber of cigarettes smoked per day within } \\
f \text { developing AEP }\end{array}$ & 13 \\
\hline No change & smoking habits & 10 \\
\hline Former smo & & $1(1)$ \\
\hline Never-smok & & $1(1)$ \\
\hline Time from in & iation of smoking to presentation days ${ }^{\#}$ & $17(13-26)$ \\
\hline \multicolumn{3}{|c|}{ Symptoms } \\
\hline Cough & & $130(95)$ \\
\hline Dyspnoea & & $127(93)$ \\
\hline Fever & & $120(88)$ \\
\hline Chill & & $76(56)$ \\
\hline Headache & & $40(29)$ \\
\hline Myalgia & & $31(23)$ \\
\hline Chest pain & & $22(16)$ \\
\hline Inspiratory c & ackle on chest auscultation & $92(67)$ \\
\hline \multicolumn{3}{|c|}{ Laboratory findings } \\
\hline White blood & ell count cells $\cdot \mu \mathrm{L}^{-1}$ & $12070(9435-16835)$ \\
\hline Leukocytos & $>10000$ cells $\cdot \mu L^{-1}$ & $97(71)$ \\
\hline Peripheral e & sinophil count cells $\mu \mathrm{L}^{-1}$ & $360(220-583)$ \\
\hline Eosinophili & $>500$ cells $\cdot \mu \mathrm{L}^{-1}$ & $44(32)$ \\
\hline C-reactive $p$ & tein $\mathbf{m g} \cdot \mathrm{dL}^{-1}$ & $16.6(9.1-36.6)$ \\
\hline $\mathrm{Pa}, \mathrm{O}_{2} / \mathrm{Fl}_{1} \mathrm{O}_{2} \mathrm{ra}$ & & $284.3(232.7-334.1)$ \\
\hline Eosinophils & n BAL \% & $40(35-53)$ \\
\hline Lymphocyte & on BAL \% & $19(12-28)$ \\
\hline Neutrophil o & BAL $\%$ & $5(2-11)$ \\
\hline Admitted to & & $108(79)$ \\
\hline Need for me & hanical ventilation & $3(2)$ \\
\hline Invasive & & 2 \\
\hline Noninvasiv & & 1 \\
\hline
\end{tabular}

Data are presented as $n(\%)$, median (interquartile range) or $\mathrm{n} . \mathrm{Pa}_{\mathrm{a}} \mathrm{O}_{2}$ : arterial oxygen tension: $\mathrm{Fl}, \mathrm{O}_{2}$ : inspiratory oxygen fraction; $\mathrm{BAL}$ : bronchoalveolar lavage; ICU: intensive care unit. " : time from initiation of smoking or increased number of cigarettes to presentation of symptoms in 125 patients who had changed their smoking habits.

were administered intravenous methylprednisolone for 3 days followed by oral prednisolone and 37 patients received oral prednisolone only. 42 patients received a 4 -week course of treatment and 85 patients received a 2-week course of treatment. The remaining $10(7 \%)$ patients did not receive any corticosteroid treatment based on their symptoms and degree of oxygenation,

\begin{tabular}{lc} 
TABLE 2 & $\begin{array}{l}\text { High-resolution computed tomography (HRCT) } \\
\text { findings at the time of presentation in 137 } \\
\text { patients with acute eosinophilic pneumonia }\end{array}$ \\
\hline HRCT findings & Patients \\
\hline Ground-glass opacity & $133(97)$ \\
Interlobular septal thickening & $93(68)$ \\
Centrilobular nodules & $71(52)$ \\
Air-space consolidation & $51(37)$ \\
Thickening of bronchovascular bundles & $24(18)$ \\
Pleural effusion & $121(88)$ \\
$\quad$ Bilateral & 107 \\
Unilateral & 14 \\
\hline & \\
Data are presented as $\mathrm{n}(\%)$ or $\mathrm{n}$.
\end{tabular}

but improved spontaneously. All symptoms improved after a median of 7 (4-10) days; defervescence occurred within $48 \mathrm{~h}$ in all patients and dyspnoea was improved within 3 (2-5) days. Median counts of peripheral eosinophil decreased to 129 (48472) cells $\cdot \mathrm{mL}^{-1} 7$ days after corticosteroid treatment. However, the eosinophil counts increased again 14 days after the treatment (284 (92-743) cells $\cdot \mathrm{mL}^{-1}$ ) compared to those at 7 days after the treatment. This trend was also observed in frequencies of eosinophilia $\left(>500\right.$ cells $\left.\cdot \mu \mathrm{L}^{-1}\right)$ after treatment $(24 \%$ at 7 days and $36 \%$ at 14 days) (table 3 ). At 7 days, both pulmonary infiltrates and pleural effusion were still visible on chest radiographs in 19 (15\%) patients. HRCT taken at 14 days showed pulmonary infiltrates present in $13(10 \%)$ patients and pleural effusion present in three $(2 \%)$ patients. Adverse effects were noted in $25(20 \%)$ patients. One patient developed herpes zoster, 12 (9\%) patients developed epigastric pain and $14(11 \%)$ patients developed dyspepsia.

Severity of respiratory failure as measured by $\mathrm{Pa}_{\mathrm{a}} \mathrm{O}_{2} / \mathrm{FI}, \mathrm{O}_{2}$ ratios correlated inversely with improvement of dyspnoea $(\rho=$ $-0.329, p<0.001)$, discontinuation of oxygen $(\rho=-0.463, p<0.001)$ and ICU stay $(\rho=-0.287, p=0.003)$ (table 4$)$.

All patients were discharged with complete resolution of symptoms and radiologic abnormalities. A total of $42(31 \%)$ patients were followed up for 74 (60-153) days after discharge from the hospital. Of these 42 patients, 23 (55\%) had started smoking again, but an AEP relapse occurred in only one patient who resumed smoking 44 days after stopping cigarette smoking.

\section{Comparison of efficacy of 2 weeks versus 4 weeks of corticosteroid treatment}

Comparisons of baseline characteristics of patients who received 2 weeks and 4 weeks of corticosteroid treatment are summarised in table 5. Patients who received corticosteroid treatment for 4 weeks were more likely to have a fever and inspiratory crackle on chest auscultation when compared with those who received corticosteroid treatment for 2 weeks. CRP levels and neutrophil counts in BAL fluid were significantly higher and $\mathrm{Pa}, \mathrm{O}_{2} / \mathrm{FI}, \mathrm{O}_{2}$ ratio was significantly lower in the 4 -week group. After adjusting for fever, myalgia, crackle on chest auscultation, C-reactive protein, peripheral eosinophilia and neutrophil count in BAL 


\begin{tabular}{|c|c|c|}
\hline TABLE 3 & \multicolumn{2}{|c|}{$\begin{array}{l}\text { Treatment responses in } 127 \text { patients with acute } \\
\text { eosinophilic pneumonia who received } \\
\text { corticosteroid treatment }\end{array}$} \\
\hline \multicolumn{2}{|c|}{ Corticosteroid treatment } & $127(93)$ \\
\hline \multicolumn{2}{|c|}{$\begin{array}{l}\text { Intravenous methylprednisolone followed by oral } \\
\text { prednisolone }\end{array}$} & 90 \\
\hline \multicolumn{2}{|c|}{ Oral prednisolone only } & 37 \\
\hline \multicolumn{2}{|c|}{ No treatment } & $10(7)$ \\
\hline \multicolumn{3}{|c|}{ Clinical outcomes } \\
\hline \multicolumn{2}{|c|}{ Time to defervescence days } & $0(0-1)$ \\
\hline \multicolumn{2}{|c|}{ Time to improved dyspnoea days } & $3(2-5)$ \\
\hline \multicolumn{2}{|c|}{ Time to discontinuation of oxygen supplement days } & $2(0-4)$ \\
\hline \multicolumn{2}{|c|}{ Time to disappearance of all symptoms days } & $7(4-10)$ \\
\hline \multicolumn{2}{|c|}{ Duration of ICU stay days } & $2(2-3)$ \\
\hline \multicolumn{2}{|c|}{ Mortality } & $0(0)$ \\
\hline \multicolumn{3}{|c|}{ Laboratory outcomes } \\
\hline \multicolumn{2}{|c|}{ Peripheral eosinophil count at 7 days cells $\cdot \mu \mathrm{L}^{-1}$} & $129(48-472)$ \\
\hline \multicolumn{2}{|c|}{ Eosinophilia $>500$ cells $\cdot \mu \mathrm{L}^{-1}$ at 7 days } & $31(24)$ \\
\hline \multicolumn{2}{|c|}{ Peripheral eosinophil count at 14 days cells $\mu \mathrm{L}^{-1}$} & $284(92-743)$ \\
\hline \multicolumn{2}{|c|}{ Eosinophilia $>500$ cells $\cdot \mu \mathrm{L}^{-1}$ at 14 days } & $46(36)$ \\
\hline \multicolumn{2}{|c|}{ C-reactive protein at 7 days $\mathrm{mg} \cdot \mathrm{dL}^{-1}$} & $0.28(0.13-0.50)$ \\
\hline \multicolumn{2}{|c|}{ C-reactive protein at 14 days $\mathrm{mg} \cdot \mathrm{dL}^{-1}$} & $0.13(0.02-0.50)$ \\
\hline \multicolumn{3}{|c|}{ Radiological outcomes } \\
\hline \multicolumn{2}{|c|}{ Pulmonary infiltrates visible on chest radiograph at 7 days } & $19(15)$ \\
\hline \multicolumn{2}{|c|}{ Pleural effusion visible on chest radiograph at 7 days } & $19(15)$ \\
\hline \multicolumn{2}{|c|}{ Pulmonary infiltrates visible on HRCT at 14 days } & $13(10)$ \\
\hline \multicolumn{2}{|c|}{ Pleural effusion visible on HRCT at 14 days } & $3(2)$ \\
\hline \multicolumn{2}{|c|}{ Adverse effect of corticosteroid } & $25(20)$ \\
\hline \multicolumn{2}{|c|}{ Herpes zoster } & $1(1)$ \\
\hline \multicolumn{2}{|c|}{ Epigastric pain } & $12(9)$ \\
\hline \multicolumn{2}{|c|}{ Dyspepsia } & $14(11)$ \\
\hline
\end{tabular}

Data are presented as $\mathrm{n}(\%), \mathrm{n}$ or median (interquartile range). ICU: intensive care unit; HRCT: high-resolution computed tomography.

fluid, the mean and proportion of patients were calculated in order to compare the efficacy of corticosteroid treatment between the 2- and 4-week groups (table 6). Differences in adjusted mean (95\% confidence interval) for times to defervescence, resolution of dyspnoea and disappearance of all symptoms were $0.11(-0.26-0.49)$ days, $0.57(-0.71-1.86)$ days and -0.04 (-1.91-1.83) days, respectively. The difference in adjusted proportion for patients whose pulmonary infiltration was visible on HRCT at 14 days was $6.92(-8.19-22.02) \%$. In addition, the frequency of adverse effects was similar between the 2- and 4week group ( $18 \%$ versus $24 \%, \mathrm{p}=0.411)$.

\section{DISCUSSION}

AEP is thought to be a rare disease and there is a limited number of case series, all with relatively small sample sizes, that have been reported in the medical literature [1, 3, 5, 6, 10, 13-15]. That said, studies with larger samples afford the best picture of the clinical characteristics of this disease. Although the present study data came from a single centre referral military hospital, 137 cases of AEP were identified. The main reason why very high number of patients could be collected in a single centre over a relatively short period is due to the unique characteristics of the medical system in the Korean army. According to the military law of the Korean army, all soldiers should be treated in

\begin{tabular}{|c|c|c|c|}
\hline \multirow{2}{*}{\multicolumn{2}{|c|}{ 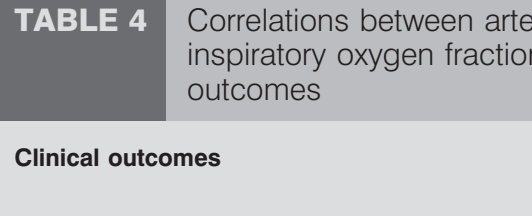 }} & \multicolumn{2}{|c|}{$\begin{array}{l}\text { rial oxygen tension/ } \\
\text { n ratio and clinical }\end{array}$} \\
\hline & & $\begin{array}{l}\text { Correlation } \\
\text { coefficient }(\rho)\end{array}$ & p-value \\
\hline \multicolumn{2}{|c|}{ Time to defervescence days } & -0.071 & 0.411 \\
\hline \multicolumn{2}{|c|}{ Time to improved dyspnoea days } & -0.329 & $<0.001$ \\
\hline \multicolumn{2}{|c|}{$\begin{array}{l}\text { Time to discontinuation of oxygen } \\
\text { supplement days }\end{array}$} & -0.463 & $<0.001$ \\
\hline \multicolumn{2}{|c|}{ Time to disappearance of all symptoms days } & -0.146 & 0.090 \\
\hline \multicolumn{2}{|c|}{ Duration of intensive care unit stay days } & -0.287 & 0.003 \\
\hline
\end{tabular}

military hospitals. The Armed Forces Capital Hospital is the only tertiary referral military hospital in Korea where bronchoscopy is available. Accordingly, all patients with suspected AEP should be transferred to the Armed Forces Capital Hospital. Although this study is single centre, enrolled patients were transferred from more than 20 military hospitals. Therefore, our cohort represented all young males at risk for AEP in the Korean army. This relatively large case series confirms clinical characteristics, radiological findings and responsiveness to standardised corticosteroid treatment previously reported in smaller case series [2]. Additionally, this series indicates that a 2week short-course of corticosteroid treatment might be acceptable for treatment of AEP with respiratory failure.

The aetiology of AEP is unknown, but several series have suggested that cigarette smoke is related to the onset of $\operatorname{AEP}[3,5$, 7]. Most of the patients (99\%) in this study were current smokers, and the majority had either restarted smoking after cessation or had started smoking for the first time within 1 month prior to presentation. The median duration from initiation of smoking to presentation of symptoms was 17 days, which is consistent with previous reports [3,9]. Additionally, within 1 month before onset of AEP, 13 patients increased the number of cigarettes they smoked daily. Therefore, the study results support the theory that recent changes in smoking habits, including restarting after cessation and increasing the number of daily cigarettes, are associated with the development of AEP [3].

Hypoxaemic respiratory failure is frequently identified at presentation and often requires mechanical ventilation in patients with AEP. In the present study, $\sim 60 \%$ of the patients presented with acute respiratory failure with decreased oxygenation. However, mechanical ventilation was required in only three patients. In addition, some patients did not progress to severe respiratory failure and then had a spontaneous recovery without any treatment. Interestingly, $16-27 \%$ of patients improved without definite treatment in the previous studies [5, 14]. UCHIYAMA et al. [3] reported that the majority of patients with AEP spontaneously improved without any treatment. Therefore, the clinical course and severity of AEP appear to be even more varied than originally reported [1].

Although spontaneous improvements have even been reported in patients with severe respiratory failure [5], death from AEP with respiratory failure can occur $[7,16]$. In earlier case series, therefore, treatments with a high dose of corticosteroid were 
TABLE 5 Comparisons of baseline characteristics of patients who received corticosteroid treatment for 2 weeks and 4 weeks

\begin{tabular}{|c|c|c|c|}
\hline Characteristics & 2 weeks & 4 weeks & p-value \\
\hline Subjects $\mathbf{n}$ & 85 & 42 & \\
\hline History of allergic disease & $8(10)$ & $3(10)$ & 1.000 \\
\hline Time from initiation of smoking to presentation days ${ }^{\#}$ & $17(14-28)$ & $16(11-24)$ & 0.435 \\
\hline \multicolumn{4}{|l|}{ Symptoms } \\
\hline Fever & $69(81)$ & $41(98)$ & 0.011 \\
\hline Chill & $46(54)$ & $26(62)$ & 0.405 \\
\hline Headache & $28(33)$ & $11(26)$ & 0.438 \\
\hline Myalgia & $27(32)$ & $3(7)$ & 0.002 \\
\hline Chest pain & $13(15)$ & $5(12)$ & 0.606 \\
\hline C-reactive protein $\mathrm{mg} \cdot \mathrm{dL}^{-1}$ & $12.1(5.9-31.4)$ & $35.6(16.3-38.4)$ & $<0.001$ \\
\hline $\mathrm{Pa}, \mathrm{O}_{2} / \mathrm{Fl}_{1} \mathrm{O}_{2}$ ratio & 298.7 (262.9-344.8) & 239.1 (219.3-268.8) & $<0.001$ \\
\hline Eosinophils on BAL \% & $40(35-53)$ & $40(31-50)$ & 0.078 \\
\hline Lymphocytes on BAL \% & $19(12-26)$ & $23(12-30)$ & 0.747 \\
\hline Neutrophil on BAL \% & $5(2-10)$ & $6(4-17)$ & 0.004 \\
\hline
\end{tabular}

Data are presented as median (interquartile range) or $\mathrm{n}(\%)$, unless otherwise stated. $\mathrm{Pa}_{\mathrm{a}} \mathrm{O}_{2}$ : arterial oxygen tension: $\mathrm{Fl}, \mathrm{O}_{2}$ : inspiratory oxygen fraction; BAL: bronchoalveolar lavage. ${ }^{\#}$ : data were available in 131 (97\%) patients who were current smokers.

initiated and rapid improvements were reported $[1,6,15,17$, $18]$. In the present study, patients with AEP were uniformly responsive to intravenous or oral corticosteroid treatment. Interestingly, the improvements of clinical outcomes were correlated with severity of respiratory failure at presentation. In addition, the majority of pulmonary infiltrates on chest radiographs disappeared within 7 days after corticosteroid treatment, which is consistent with previous reports [7]. However, when some patients were evaluated with computed tomography scan at 14 days, pulmonary infiltrates and pleural effusion were still present. During the follow-up period, relapse occurred in only one patient who resumed smoking 1.5 months

\section{TABLE 6 Comparison of adjusted means or proportion of clinical outcomes of patients who received corticosteroid treatment for 2 weeks and 4 weeks}

Difference between adjusted mean or proportion $(95 \% \mathrm{Cl})$

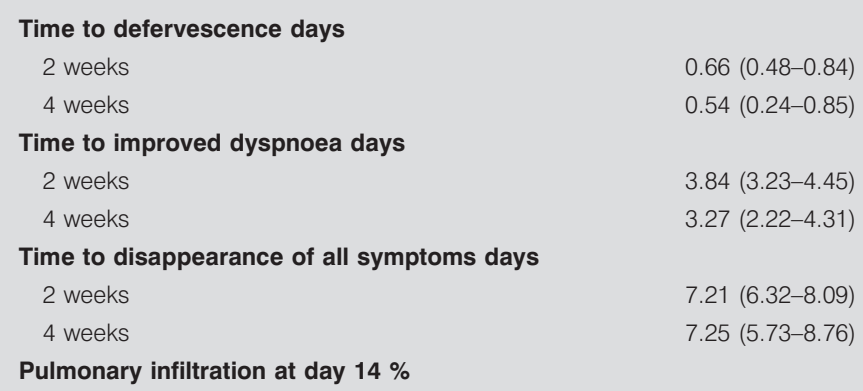


after cessation of cigarette smoking. Although previous reports had suggested that no relapses occurred in patients recovered from AEP, three additional cases of relapsed AEP are reported in the recent literature $[3,19,20]$. Interestingly, cases involving AEP relapse, including the relapse reported in the present study, are associated with resumption of smoking after temporary cessation. These observations suggest that relapse of AEP can occur in patients who resume cigarette smoking. However, the remaining 23 patients who resumed cigarette smoking in this study did not have an AEP relapse.

There is no standardised regimen of corticosteroid treatment for AEP. The literature discusses proposed and implemented regimens of corticosteroids that span a wide range of doses and durations [2]. A commonly recommended regimen is 60 $125 \mathrm{mg}$ intravenous methylprednisolone every $6 \mathrm{~h}$, changing to $40-60 \mathrm{mg}$ of oral prednisone daily tapering over 2-6 weeks [21]. However, the optimal duration of corticosteroid treatment is uncertain and has not been subjected to controlled trials [4]. This is the first study that showed clinical efficacy of standardised treatment of corticosteroids for AEP. Patients in this study were treated according to the standardised corticosteroid protocol based on the severity of disease [21], but we changed the duration of the taper from 4 weeks to 2 weeks. This made it possible to compare the efficacy and safety of 2-week versus 4-week courses of treatment. Interestingly, the efficacy of a 2-week course of corticosteroid was similar to that of a 4-week course in terms of time to resolution of clinical symptoms and resolution of radiological abnormalities. In addition, the frequency of adverse effects was also similar between the groups. These might be because a similar dosage of corticosteroid is administered during the first week of treatment in both the 2week and 4 -week regimen (fig. 1). The primary difference between the regimens was the corticosteroid tapering schedule. Therefore, the results of this study suggest that high doses of corticosteroid could be tapered over periods as short as 10 days. This is supported by the results of previous studies $[1,6]$. In addition, recently reported cases from Japan received only high doses of corticosteroids intravenously for 3 days without a maintenance treatment of oral prednisolone [3]. However, these observations should be further evaluated by a prospective study.

There are several limitations to this study. First, given its retrospective nature, there is always the possibility that selection bias might have influenced the significance of our findings. However, the data were collected prospectively from all consecutive patients with AEP. Patient history, especially in terms of smoking, AEP confirmation tests and corticosteroid treatment was taken according to standardised protocol. Secondly, this study was conducted at a single military hospital and all of the enrolled patients were young males, which may limit the ability to generalise our findings to other centres or populations. However, previous reports showed that AEP develops predominantly in young patients $[1,3,5,7]$. Finally, the baseline characteristics of the patients were not balanced when comparing the efficacies between short and long courses of corticosteroid treatment. This was addressed by the adjusted multivariate analysis. However, the potential for bias due to an unmeasured confounder remains.

In conclusion, in addition to further clarifying the major clinical characteristics of AEP and the association between recent changes in smoking habits and development of AEP, this study suggests that respiratory symptoms of AEP can vary from mild dyspnoea to life-threatening respiratory failure. This study also found that 2 weeks of corticosteroid treatment for patients with respiratory failure could be as effective as 4 weeks of treatment, although this observation needs to be further evaluated by a prospective study.

\section{STATEMENT OF INTEREST}

None declared.

\section{ACKNOWLEDGEMENTS}

The authors thank S. Woo (Samsung Biomedical Research Institute, Seoul, Republic of Korea) for comments regarding statistical analysis.

\section{REFERENCES}

1 Allen JN, Pacht ER, Gadek JE, et al. Acute eosinophilic pneumonia as a reversible cause of noninfectious respiratory failure. $N$ Engl J Med 1989; 321: 569-574.

2 Janz DR, O'Neal HR Jr., Ely EW. Acute eosinophilic pneumonia: a case report and review of the literature. Crit Care Med 2009; 37: 1470-1474.

3 Uchiyama H, Suda T, Nakamura Y, et al. Alterations in smoking habits are associated with acute eosinophilic pneumonia. Chest 2008; 133: 1174-1180.

4 Allen J. Acute eosinophilic pneumonia. Semin Respir Crit Care Med 2006; 27: 142-147.

5 Philit F, Etienne-Mastroianni B, Parrot A, et al. Idiopathic acute eosinophilic pneumonia: a study of 22 patients. Am J Respir Crit Care Med 2002; 166: 1235-1239.

6 Pope-Harman AL, Davis WB, Allen ED, et al. Acute eosinophilic pneumonia. A summary of 15 cases and review of the literature. Medicine (Baltimore) 1996; 75: 334-342.

7 Shorr AF, Scoville SL, Cersovsky SB, et al. Acute eosinophilic pneumonia among US military personnel deployed in or near Iraq. JAMA 2004; 292: 2997-3005.

8 Baughman RP. Technical aspects of bronchoalveolar lavage: recommendations for a standard procedure. Semin Respir Crit Care Med 2007; 28: 475-485.

9 Halm EA, Fine MJ, Marrie TJ, et al. Time to clinical stability in patients hospitalized with community-acquired pneumonia: implications for practice guidelines. JAMA 1998; 279: 1452-1457.

10 Daimon $\mathrm{T}$, Johkoh $\mathrm{T}$, Sumikawa $\mathrm{H}$, et al. Acute eosinophilic pneumonia: thin-section CT findings in 29 patients. Eur J Radiol 2008; 65: 462-467.

11 Fisher B, Anderson S, Fisher ER, et al. Significance of ipsilateral breast tumour recurrence after lumpectomy. Lancet 1991; 338: 327-331.

12 Jeon EJ, Kim KH, Min KH. Acute eosinophilic pneumonia associated with 2009 influenza A (H1N1). Thorax 2010; 65: 268-270.

13 Hayakawa H, Sato A, Toyoshima M, et al. A clinical study of idiopathic eosinophilic pneumonia. Chest 1994; 105: 1462-1466.

14 Umeki S. Reevaluation of eosinophilic pneumonia and its diagnostic criteria. Arch Intern Med 1992; 152: 1913-1919.

15 Tazelaar HD, Linz LJ, Colby TV, et al. Acute eosinophilic pneumonia: histopathologic findings in nine patients. $A m J$ Respir Crit Care Med 1997; 155: 296-302.

16 Kawayama T, Fujiki R, Morimitsu Y, et al. Fatal idiopathic acute eosinophilic pneumonia with acute lung injury. Respirology 2002; 7: 373-375.

17 Badesch DB, King TE Jr., Schwarz MI. Acute eosinophilic pneumonia: a hypersensitivity phenomenon? Am Rev Respir Dis 1989; 139: 249-252. 
18 King MA, Pope-Harman AL, Allen JN, et al. Acute eosinophilic pneumonia: radiologic and clinical features. Radiology 1997; 203: 715-719.

19 Shiota Y, Kawai T, Matsumoto H, et al. Acute eosinophilic pneumonia following cigarette smoking. Intern Med 2000; 39: 830-833.
20 Shintani H, Fujimura M, Yasui M, et al. Acute eosinophilic pneumonia caused by cigarette smoking. Intern Med 2000; 39: 66-68.

21 Jantz MA, Sahn SA. Corticosteroids in acute respiratory failure. Am J Respir Crit Care Med 1999; 160: 1079-1100. 